\title{
Do Price Discreteness and Transactions Costs Affect Stock Returns? Comparing Ex-Dividend Pricing Before and After Decimalization
}

\author{
JOHN R. GRAHAM, RONI MICHAELY, and MICHAEL R. ROBERTS*
}

\begin{abstract}
By the end of January 2001, all NYSE stocks had converted their price quotations from $1 / 8 \mathrm{~s}$ and $1 / 16 \mathrm{~s}$ to decimals. This study examines the effect of this change in price quotations on ex-dividend day activity. We find that abnormal ex-dividend day returns increase in the $1 / 16$ and decimal pricing eras, relative to the $1 / 8$ era, which is inconsistent with microstructure explanations of exday price movements. We also find that abnormal returns increase in conjunction with a May 1997 reduction in the capital gains tax rate, as they should if relative taxation of dividends and capital gains affects ex-day pricing.
\end{abstract}

IF CAPITAL MARKETS WERE PERFECT, a stock's price would fall by the amount of the dividend on the ex-day. Instead, the ratio of price drop to dividend, known as the ex-day premium, has been consistently below one for decades (e.g., Elton and Gruber (1970), Michaely (1991), or Eades, Hess and Kim (1994)). Several lines of reasoning have developed to explain the ex-day phenomenon: (1) differential taxation between dividends and capital gains, (2) the interaction of taxes and transactions costs to trading stocks, and (3) price discreteness and bid-ask bounce. U.S. markets during the past half-dozen years offer a natural experiment to test these hypotheses. During this time, price discreteness and bid-ask spreads fell dramatically, allowing us to test the microstructure-based explanations. At the same time, the capital gains tax rate dropped from $28 \%$ to $20 \%$, which permits examination of the tax hypothesis.

The most significant change during the time period of this study is the reduction in the minimum tick size from $1 / 8$ to $1 / 16$ to decimals. This change allows us to directly test several microstructure explanations for why the average ex-divi-

\footnotetext{
* Graham is from Duke University, Michaely is from Cornell University and IDC, and Roberts is from Duke University. We thank an anonymous referee, Michael Bradley, Alon Brav, Magnus Dahlquist, David Freedman, Kenny Garbade, Rick Green (the editor), Charles Himmelberg, David Hsieh, Pete Kyle, Uri Loewenstein, Jim Mahoney, Chris Mayer, Emma Rasiel, Doug Shackelford, Vish Viswanathan, Ralph Walkling, Bob Whaley, and seminar participants at Duke, Ohio State, and the Federal Reserve Board of New York for comments. We are responsible for all remaining errors. Graham acknowledges financial support from an Alfred P. Sloan Research Fellowship.
} 
dend day price drop is less than the dividend amount. Bali and Hite (1998) argue that the premium deviates from one because of price discreteness. They claim that the ex-day price of a stock will change by the price increment equal to, or just smaller than, the size of the dividend payment. For example, with a minimum bid-ask spread of $\$ 1 / 8$, a $\$ 0.20$ dividend would lead to a $\$ 0.125$ drop in share price, which translates into an ex-dividend premium of 0.625 .

Frank and Jagannathan (1998) also propose a microstructure explanation for the premium deviating from one. They argue that market makers have a comparative cost advantage to handling dividends, so they purchase stocks cum-dividend (at the bid price) to receive ownership of the upcoming dividend and then sell (at the ask price) shortly after the stocks go ex-dividend. The resulting bid-ask bounce induces a positive price movement that shows up as an abnormally high before-tax ex-day stock return (dividend plus capital gain).

The decline in minimum tick size allows us to directly test these theories. Though later sections develop more refined empirical hypotheses, the basic prediction of the microstructure theories is that this decline in minimum tick size and associated reduction in bid-ask spread should increase the average ex-day premium, so that it is closer to one.

The May 7, 1997 reduction in the capital gains tax rate from $28 \%$ to $20 \%$ allows us to test a tax hypothesis as well. The tax argument is that the price drop is less than the dividend because high personal taxes on dividends (relative to capital gains) reduce the value of the dividend (e.g., Elton and Gruber (1970), Litzenberger and Ramaswamy (1979), Lakonishok and Vermaelen (1986), Karpoff and Walkling (1990), and Michaely and Vila (1995)). These papers also find that the premium is smaller for low dividend-yield stocks, which is consistent with high (low) tax rate investors preferring stocks that provide capital gains (dividends). The tax hypothesis implies that the 1997 increase in dividend taxation (relative to capital gains) should reduce premiums.

The third argument used to explain the ex-day phenomenon focuses on how the interaction of transactions costs, taxes, and risk affects ex-day price and volume behavior (e.g., Kalay (1982), Lakonishok and Vermaelen (1986), Karpoff and Walkling (1988, 1990), Boyd and Jagannathan (1994), and Michaely, Vila, and Wang (1997), among others). Kalay, for example, shows that if transaction costs are large and render arbitrage trades unprofitable, then the relative taxation of dividends and capital gains should be reflected in prices. In contrast, if transaction costs are small, arbitrageurs trade around the ex-day and affect prices. In these papers, transactions costs (and risk exposure) restrict arbitrage and dividend capture trading beyond some point, and therefore in equilibrium, the value of the premium may deviate from one. We find that the median effective ex-day bid-ask spread fell from 0.125 to 0.0625 to 0.020 in the $1 / 8,1 / 16$, and decimal eras, respectively. This large reduction in spreads occurs because of reduced coarseness in the pricing grid and permits a test of the transaction costs models. As transaction costs decrease, more arbitrage trades should take place and the average premium should increase, and become closer to one, especially for those stocks that experienced the greatest reduction in 
spreads. ${ }^{1}$ A related prediction is that trading volume, and especially large arbitrage trades, should increase.

Our results indicate that ex-day premiums fell, and abnormal returns increased, as the pricing grid changed from $1 / 8$ to $1 / 16$ to decimals. This is evidence against the ex-dividend day premium deviating from one due to price discreteness (either directly as in Bali and Hite (1998) or indirectly via its effect on bidask bounce as in Frank and Jagannathan (1998)). The recent results of Jakob and $\mathrm{Ma}$ (2004) complement our findings related to Bali and Hite. Jakob and Ma find that the cum- to ex-day price drops are equally likely to equal the tick above the dividend or below the dividend, which is directly against Bali and Hite's assumption that prices are always rounded down. They also confirm our finding that the premium did not get closer to one with the move away from $1 / 8$ pricing.

To the extent that spreads are the dominant transaction cost for ex-day traders, our evidence is also inconsistent with an implication of the transaction cost models. Moreover, while we document abnormal trading activity among high dividend-yield stocks (like previous studies), we do not find an increase in abnormal volume as bid-ask spreads fell. This evidence about transaction cost models is not supportive. However, we also consider the possibility that investors, especially large traders, are affected not only by spreads but also by depth. We find that during this time period, overall depth fell, which could imply that the reduction in spreads does not translate into an overall decrease in transaction costs for some traders, which in turn might explain why ex-day abnormal returns did not decrease with decimalization.

While our results are not consistent with microstructure explanations, the reduction in the average ex-day premium that occurred as the capital gains tax rate fell is consistent with the tax hypothesis. The reduction of the median premium from 0.89 in the $1 / 8$ era to 0.83 in the $1 / 16$ era to 0.75 in the decimal era is economically large, and also of the appropriate magnitude given the size of the capital gains tax rate reduction. This result in support of the tax hypothesis is consistent with Barclay (1987), Green and Rydqvist (1999), McDonald (2001), and Bell and Jenkinson (2002), who also find evidence consistent with the notion that differential taxation of dividends relative to capital gains affects the ex-day premium (see Graham (2003) for a review).

The issues investigated in this paper are of central importance to corporate finance and asset pricing, as well as to corporate finance practitioners (see Brav et al. (2003)). It is important to understand the degree to which investor taxes and transactions costs are impounded into security prices, which in turn can affect security returns, the cost of capital, capital structure, investment spending, and governmental revenue collection. Further, it is interesting to understand

\footnotetext{
${ }^{1}$ This presumes that bid-ask spreads are the relevant cost that inhibits trades in transaction cost models, or at least that they proxy for such costs. There are several reasons to expect that the bid-ask spread might be a reasonable measure of transaction costs. First, for many traders, the bid-ask spread is the major transaction cost of trading. Second, Stoll and Whaley (1983) show that total transaction costs and bid-ask spreads are highly correlated. Third, Karpoff and Walkling (1990) show that ex-day returns are positively correlated with the spread, consistent with transaction costs affecting ex-day returns via arbitrage trading.
} 
whether recent reductions in tick size affect trading activity for ex-dividend motivated trades.

The remainder of the paper proceeds as follows. Section I describes tax, price discreteness, and transaction cost theories that have been derived to explain ex-day premia and returns. This section also develops empirical predictions about what should happen on the ex-day, according to these theories, given the refinement of the pricing grid in the U.S. stock market. Section II describes our data sample and provides summary statistics. Section III presents our empirical results, and Section IV concludes.

\section{Theory and Empirical Hypotheses}

The explanations of ex-day price behavior can be categorized into three groups. The first is the pure tax explanation (e.g., Elton and Gruber (1970)) in which the only determinant of the price movement between the cum-day and the ex-day is dividend taxation relative to capital gains taxation. A second group suggests that the price movement between the cum-day and the ex-day is due to the market microstructure, or nontax market frictions. Bali and Hite (1998) claim that the dominant friction is price discreteness. Frank and Jagannathan (1998) argue that bid-ask bounce is the major friction. If correct, these theories provide an explanation to the ex-day phenomena unrelated to differential taxation. The third group of models recognizes that tax-based trading may be constrained by other frictions such as transaction costs and risk (e.g., Kalay (1982), Boyd and Jagannathan (1994), Michaely and Vila (1995), and Michaely et al. (1997).

The price of a stock changes from $P_{\text {cum }}$ on the last day the stock is traded with the dividend (the cum-day) to $P_{e x}$ as the stock goes ex-dividend. In a perfect, frictionless capital market, the price should fall dollar for dollar with the magnitude of the dividend payment, Div. That is,

$$
\left(P_{\text {cum }}-P_{e x}\right)=\text { Div }
$$

In the presence of differential taxes on dividends and capital gains, when a firm issues a dividend, investors receive $\operatorname{Div}\left(1-\tau_{\text {div }}\right)$ net of taxes but simultaneously avoid capital gain taxes of the amount $\left(P_{\text {cum }}-P_{\text {ex }}\right) \tau_{\text {cap gains. Ignoring risk and }}$ transaction costs, Elton and Gruber (1970) show that in equilibrium

$$
\left(P_{\text {cum }}-P_{\text {ex }}\right)\left(1-\tau_{\text {cap gains }}\right)=\operatorname{Div}\left(1-\tau_{\text {div }}\right)
$$

and therefore

$$
\text { PREM }=\frac{\left(P_{\text {cum }}-P_{e x}\right)}{\text { Div }}=\frac{\left(1-\tau_{\text {div }}\right)}{\left(1-\tau_{\text {cap gains }}\right)},
$$

where $\left(P_{\text {cum }}-P_{\text {ex }}\right) /$ Div is referred to as the ex-day premium. Assuming that clientele constituents do not vary before and after ex-days, the average ex-day premium should reflect the marginal tax rate on dividends relative to capital gains for the investors who hold the stock. 
The effect of taxes can also be expressed in terms of ex-day returns. Define an ex-dividend-day stock return as $R E T=\left(P_{\text {ex }}-P_{\text {cum }}+D i v\right) / P_{c u m}$, which may also be expressed as $R E T=(1-P R E M) *\left(D i v / P_{\text {cum }}\right)$. A premium less than one implies a return greater than zero. The higher the tax rate on dividends relative to capital gains, the smaller the premium, and the higher the ex-day return.

The capital gains tax rate fell from $28 \%$ to $20 \%$ for trades effective May 7, 1997 (which nearly coincides with the change from $1 / 8$ to $1 / 16$ pricing). The tax hypothesis predicts that premiums should fall and abnormal returns increase in conjunction with the reduction in effective capital gains tax rates.

\section{HуротнеSis 1: As capital gains tax rates fall, the ex-day premium should become smal- ler and abnormal ex-day returns should increase.}

At the other end of the spectrum, several microstructure theories argue that taxes are not the key factor affecting ex-day price behavior and that the price drop (relative to the dividend paid) can be explained by market frictions such as price discreteness and bid-ask spreads. Focusing on price discreteness, Bali and Hite (1998) argue that cum- to ex-day stock price changes are rounded to the tick below the dividend amount. If the dividend is not a multiple of the minimum tick size, the price will fall by less than the full amount of the dividend when it goes ex-dividend. ${ }^{2}$ Bali and Hite argue that price discreteness can account for premiums less than one and positive ex-dividend day returns. ${ }^{3}$ Moreover, Bali and Hite's argument implies that the greater the tick size, the further from one the premium will be. An immediate implication of their model is that the move to decimalization should lead to premiums closer to one.

Frank and Jagannathan (1998) use a different model but derive similar predictions. Frank and Jagannathan claim that dividends are a nuisance to collect and reinvest for most investors and, as such, are valued at less than face value. ${ }^{4}$ Market makers are well suited to handle dividend transactions, so they purchase more stocks than normal cum-dividend at the bid and resell them ex-dividend at the ask. This bid-to-ask price movement can lead to ex-day price drops that are smaller than normal (i.e., premiums below one and positive ex-day returns) and that are positively related to the magnitude of the bid-ask spread. Because the

\footnotetext{
${ }^{2}$ Jakob and Ma (2004) directly investigate the Bali and Hite (1998) assumption that the change in price will always be rounded to the tick size just smaller than the size of the dividend. They find that price drops are equally likely to be the tick above the dividend as below the dividend, which is inconsistent with this important assumption of the Bali and Hite model.

${ }^{3}$ Examining the impact of NYSE rule 118, Dubofsky (1992) argues that the policy of marking down open limit buy orders but leaving open limit sell orders unchanged could result in the observed ex-dividend day behavior. Dubofsky shows that price discreteness can accentuate the rule 118 effect.

${ }^{4}$ Frank and Jagannathan (1998) demonstrate that the premium is significantly less than one in Hong Kong, even though dividends and capital gains are not taxed, consistent with the nuisance hypothesis. Kadapakkam (2000) reinforces this argument by showing that when the nuisance of handling dividends (i.e., cumbersome physical settlement procedures) was greatly reduced after the advent of electronic settlement, the ratio of price change to dividend in Hong Kong became indistinguishable from 1.0.
} 
magnitude of the bid-ask spread is positively related to the extent of price discreteness, this model also predicts premiums closer to one as discreteness is reduced and minimum spreads narrow.

A common prediction from these two models is that as the minimum tick size moves from $1 / 8$ to $1 / 16$ to decimals, the ex-dividend day premium should get closer to one. In addition, the Frank and Jagannathan (1998) story also implies that regardless of the tax regime, if prices are measured at the midpoint of the bid-ask spread, the premium should be one, or at least much closer to one relative to when it is measured with closing prices. In summary, both models posit microstructure explanations, and not taxes, as the dominant cause of the ex-day premium deviating from one. These models share a common prediction regarding the effect of the reduction in price discreteness (though one can argue that the effect is direct in Bali and Hite (1998) and indirect via bid-ask bounce in Frank and Jagannathan (1998).

Hypothesis 2: As the pricing grid becomes finer, the ex-day premium should become closer to one and ex-day returns should become closer to zero.

Unique to Frank and Jagannathan's (1998) model is the notion that the premium is, to a large extent, an artifact of bid-ask bounce. This implies that measuring the average premium using the midpoint should lead to a premium closer to one. ${ }^{5}$

Hyротнеsis 2A: Both before and after decimalization, measuring the premium using midpoint pricing should lead to premiums closer to one and ex-day returns closer to zero.

Given the models' assumptions, they can also potentially explain the positive relation between the premium and the size of the dividend, even in the absence of taxes. In Bali and Hite (1998), the price change on the ex-day is determined by the distance between the dividend and the tick below the dividend. Bali and Hite note that this distance is relatively constant regardless of the size of the dividend; therefore, according to their argument, the ratio of the change in price to the dividend is smaller when dividends are large. An analogous result holds in Frank and Jagannathan (1998) because the ratio of (bid-ask bounce induced) price change to dividend is smaller when dividends are larger. In these models, if price discreteness falls, the distance between the dividend and the next lower tick (and the magnitude of bid-ask bounce) also falls, and therefore the association between premiums and dividends should not be as large.

Hүротнеsis 3: As the pricing grid becomes finer, the positive (negative) association between the premium (return) and dividend yield should weaken.

The last class of models focuses on the interaction between taxes and other market frictions such as risk (Michaely and Vila (1995)) and transaction costs

\footnotetext{
${ }^{5}$ Note that Hypothesis 2A can be tested within any of the eras and does not require a change in the fineness of the pricing grid. All of the other hypotheses in the paper are tied to changes in the pricing grid.
} 
(Kalay (1982), Karpoff and Walkling (1988, 1990), and Michaely and Vila (1996), among others). Assuming risk neutrality and using a simple arbitrage argument, Kalay focuses on the impact of transaction costs to show that if the ex-day premium is less than 1.0, tax-free arbitrageurs will purchase stocks cum-dividend and sell ex-dividend, obtaining the dividend in a risk-free transaction. Assuming a simple form of transaction costs, Kalay argues that the ex-day premium should lie within transactions cost bounds of unity:

$$
1-2 c /\left(\frac{D i v}{P_{\text {cum }}}\right) \leqslant P R E M \leqslant 1+2 c /\left(\frac{D i v}{P_{\text {cum }}}\right),
$$

where $2 c$ represents round-trip transactions costs.

The impact of transactions costs is greatest for stocks with small dividend yields. For low dividend yield stocks, high transaction costs may make arbitrage or dividend capture trading prohibitively costly. Thus, the marginal tax rate of the holding clientele (as opposed to arbitrageurs) is more likely to be reflected in the premium for low-dividend stocks. The interaction of taxes and transactions costs can thus lead to the premium in low dividend stocks reflecting the tax rate for the marginal investor(s) in these stocks. In high yield stocks, where transaction costs are less constraining, dividend capture and arbitrage trading will be more prevalent and hence the premium is more likely to reflect the relative tax rates of these groups of traders. That is, the premium will be closer to one.

To the extent that a reduction in the minimum bid-ask spread reduces the cost of transacting, then our tests of Hypotheses 2 and 3 have implications not only for the price discreteness and bid-ask bounce models, but also for the transaction costs models. In addition to the implications of Hypotheses 2 and 3, transaction cost considerations imply that stocks experiencing a greater reduction in transaction costs should also experience a larger increase in the ex-day premium towards one (or ex-day abnormal returns closer to zero).

HypotHesis 4: The stocks for which transactions costs decrease the most should have the greatest increase in premia and reduction in abnormal returns.

An additional prediction emanates from the transaction cost models. Studies by Boyd and Jagannathan (1994), Michaely and Vila (1996), and Michaely et al. (1997) suggest that as the cost of transacting decreases, the incentive for all investors (Michaely et al.) or only arbitrageurs and dividend capturers (Boyd and Jagannathan) to join the fray is greater. Thus a reduction in transaction costs should increase trading volume in general and by these types of traders in particular.

Нүротнеsis 5: As transaction costs fall, ex-dividend day abnormal trading volume should increase.

The extant empirical evidence is generally consistent with the transaction cost models. Many studies find that the premium is closest to one and abnormal ex-day volume is highest among high dividend yield and low transaction cost stocks, which is consistent with arbitrage or dividend capture activity where one would 
most expect to find it. ${ }^{6}$ To the extent that reduced coarseness of the pricing grid reduces the cost of transacting around the ex-day, we would expect that the effects of Hypotheses 4 and 5 to be most apparent in high-dividend stocks. The effects of the premium being closer to one and higher volume might also be apparent in stocks with moderate dividend yield. For moderate yield stocks, arbitrage and dividend capture trading might have been prohibitively costly in the $1 / 8$ era but more affordable, and, hence, more prevalent, in the 1/16 and/or decimal eras. Therefore, as bid-ask spreads fall, there could be a noticeable change in ex-day activity for moderate dividend yield stocks. Note, however, that the predictions in Hypotheses 2 through 5 are tests of the transactions cost models only to the extent that the bid-ask spread is an important transaction cost for ex-day trading - and to the extent that the reduction in spreads reduced the cost of transacting in general and the cost of arbitrage trades in particular.

\section{Data and Sample Selection}

Our tests compare ex-day premiums, returns, and volume in the last part of the $1 / 8$ pricing era (January 1,1996 to May 6,1997 ) to those in the $1 / 16$ era (June 24 , 1997 to August 26, 2000) and the decimal pricing era (January 29, 2001 to December 31, 2001) (e.g. Bollen and Whaley (1998)). ${ }^{7}$ We examine NYSE firms that pay taxable quarterly cash dividends to their common stockholders, as indicated by CRSP distribution code 1232. We exclude ADRs and REITs because of different tax treatment of dividends and capital gains (REITs) and incomplete data on total trading volume (ADRs). There are 1,268 firms in the 1/8 era, 1,377 in the $1 / 16$ era, and 955 in the decimal era that meet these criteria, with 759 (908) of these firms existing in both the $1 / 8(1 / 16)$ and decimal samples. ${ }^{8}$ The number of ex-dividend events in each era is $6,145,14,142$, and 3,448 , respectively. Like previous studies, we use CRSP data for most of our analysis. From CRSP, we gather daily closing prices, dividend information, and volume data.

\footnotetext{
${ }^{6}$ Lakonishok and Vermaelen (1986) show that abnormal volume is highest among high-dividend yield stocks and that it increased after the reduction in transactions costs as measured by commissions. Karpoff and Walkling (1988) demonstrate that abnormal returns are smallest among low transaction cost stocks, especially when dividend yield is high. Karpoff and Walkling (1990) find that ex-day returns increase in transaction costs, as measured by the bid-ask spread. Michaely and Vila (1996) show that abnormal volume decreases with transaction costs, as measured by the bid-ask spread or the inverse of firms' market capitalization.

${ }^{7}$ We exclude May 7, 1997 to June 23, 1997 from our main analysis because the statutory capital gains tax rate was $20 \%$ during this period. By excluding these dates, our entire $1 / 8$ era has a $28 \%$ capital gains tax rate. We also exclude August 27, 2000 to January 28, 2001 from our analysis to avoid the decimalization phase-in. Therefore, all stocks in our 1/16 era are subject to the same tick size and tax rate, and likewise for stocks in the decimal era. Finally, note that the holding period required to qualify for long-term capital gains tax treatment was 12 months in all three eras, except from July 29, 1997 to December 31, 1997, when the holding period was temporarily 18 months. In our tests, we consider whether this 18 -month holding period affects our results and find that it does not.

${ }^{8}$ Events with more than one type of distribution (e.g., liquidating dividends) are excluded from the analysis.
} 
We also gather trade and quote (TAQ) data for the firms in our sample. To avoid matching errors between the CRSP and TAQ data, we drop firms whose ticker symbol changes within an era. This screen leaves us with a sample of 1,209 firms in the $1 / 8$ era, 1,227 in the $1 / 16$ era, and 907 in the decimal era. The TAQ data allow us to examine trades and quotes during the cum- and ex-dividend trading day. We are particularly interested in closing cum-day and opening ex-day quotes, to focus on the short-run change in price that occurs when a stock goes ex-dividend. Stoll and Whaley (1990) find that it takes an average of 5 minutes for large stocks on the NYSE for the first transaction to occur after the market opens. To avoid stale quotes, we define the market open to be the first quote occurring after 9:35 a.m. or the second quote of the day, whichever occurs later in the day. (In unreported analysis, we examine alternative definitions of the market open. The results are qualitatively similar to those reported.)

Bid-ask spreads fell significantly in conjunction with the increasing fineness of the pricing grid. Table I presents summary statistics for bid-ask spreads and effective spreads on the cum- and ex-dividend days in each of the eras. The bid-ask spread is calculated as the difference between the bid and ask prices for each event (for all quotes during the day), which is then averaged across all events to arrive at the ex-day (cum-day) spread reported in the table. The effective spread

\section{Table I}

\section{Transactions Cost Summary Statistics by Era on Ex-Dividend and Cum-Dividend Days}

The sample includes quarterly dividend-paying firms listed on the NYSE that have information available in both CRSP and TAQ databases. REITs and ADRs are excluded. The 1/8 era is from January 1, 1996 to May 6, 1997. The 1/16 era is from June 24, 1997 to August 26, 2000. The decimal era is from January 29, 2001 to December 31, 2001. Values for each variable falling in the top and bottom 2.5 percentiles are set to missing to exclude outlier observations. The Effective Spread is computed as twice the difference of the transaction price and the midpoint of the most recent quote, where the quotes have been adjusted according to the Lee and Ready (1991) 5 -second rule. The $B / A$ Spread is computed as the difference between the bid and ask prices. The Cum-Day is the day before the stock goes ex-dividend (i.e., the Ex-Day). The standard error of the sample mean is denoted by SE. Standard errors equal to 0.0000 correspond to estimates less than 0.0001 .

\begin{tabular}{|c|c|c|c|c|c|c|c|}
\hline & \multirow[b]{2}{*}{ Statistic } & \multicolumn{3}{|c|}{ Effective Spread } & \multicolumn{3}{|c|}{ B/A Spread } \\
\hline & & $\begin{array}{l}1 / 8 \\
\text { Era }\end{array}$ & $\begin{array}{l}1 / 6 \\
\text { Era }\end{array}$ & $\begin{array}{c}\text { Decimal } \\
\text { Era }\end{array}$ & $\begin{array}{l}1 / 8 \\
\text { Era }\end{array}$ & $\begin{array}{l}1 / 16 \\
\text { Era }\end{array}$ & $\begin{array}{c}\text { Decimal } \\
\text { Era }\end{array}$ \\
\hline Cum-Day & $\begin{array}{l}\text { Median } \\
\text { Mean } \\
\text { SE }\end{array}$ & $\begin{array}{c}0.1250^{\mathrm{a}} \\
0.1136^{\mathrm{a}} \\
(0.0001)\end{array}$ & $\begin{array}{c}0.0625^{\mathrm{b}} \\
0.0802^{\mathrm{b}} \\
(0.0000)\end{array}$ & $\begin{array}{c}0.0200^{\mathrm{c}} \\
0.0380^{\mathrm{c}} \\
(0.0000)\end{array}$ & $\begin{array}{c}0.1250^{\mathrm{a}} \\
0.1794^{\mathrm{a}} \\
(0.0001)\end{array}$ & $\begin{array}{c}0.1250^{\mathrm{b}} \\
0.1336^{\mathrm{b}} \\
(0.0000)\end{array}$ & $\begin{array}{c}0.0500^{c} \\
0.0629^{c} \\
(0.0000)\end{array}$ \\
\hline Ex-Day & $\begin{array}{l}\text { Median } \\
\text { Mean } \\
\text { SE }\end{array}$ & $\begin{array}{c}0.1250^{\mathrm{a}} \\
0.1136^{\mathrm{a}} \\
(0.0001)\end{array}$ & $\begin{array}{c}0.0625^{\mathrm{b}} \\
0.0803^{\mathrm{b}} \\
(0.0000)\end{array}$ & $\begin{array}{c}0.0300^{\mathrm{c}} \\
0.0384^{\mathrm{c}} \\
(0.0000)\end{array}$ & $\begin{array}{c}0.1250^{\mathrm{a}} \\
0.1811^{\mathrm{a}} \\
(0.0001)\end{array}$ & $\begin{array}{c}0.1250^{\mathrm{b}} \\
0.1329^{\mathrm{b}} \\
(0.0000)\end{array}$ & $\begin{array}{c}0.0500^{\mathrm{c}} \\
0.0624^{\mathrm{c}} \\
(0.0000)\end{array}$ \\
\hline
\end{tabular}

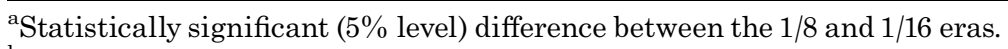

${ }^{\mathrm{b}}$ Statistically significant (5\% level) difference between the $1 / 16$ and decimal eras.

${ }^{\mathrm{c}}$ Statistically significant (5\% level) difference between the $1 / 8$ and decimal eras. 
is calculated as two times the difference between the transaction price and the midpoint of the most recent quote (for all trades during either the ex-day or the cum-day), averaged across all events. ${ }^{9}$ Both series are adjusted for outliers by trimming the top and bottom 2.5 percentiles of the distribution. The differences in spreads between the pre- and postdecimalization eras are dramatic. For example, measured on the cum-dividend days, the average effective spread fell from 0.114 in the $1 / 8$ era to 0.038 in the decimal era, a drop of over $65 \%$. Similar results are obtained on ex-days, or when using median changes instead of mean changes. These results are consistent with the more general findings in the NYSE Report (New York Stock Exchange, 2001), Bessembinder (2001), and Edwards (2001) of falling spreads as minimum spreads were reduced. Thus, what we find here is not unique to the ex-day but holds in general. ${ }^{10}$

\section{Empirical Analysis}

\section{A. Ex-Dividend Day Premia and Abnormal Returns (Tests of Hypotheses 1 and 2)}

\section{A.1. Closing Prices Using CRSP Data}

Table II presents ex-day premia during the $1 / 8,1 / 16$, and decimal eras. Panel A shows the results for all observations in a given era. The median premium is 0.89 in the $1 / 8$ era, 0.83 in the $1 / 16$ era, and 0.75 in the decimal era. We focus on the median because the premium is highly volatile and its distribution has extremely fat tails. The high variance and kurtosis in the premium distribution are caused by observations with a large numerator (price change) and/or a very small denominator (dividends). So that outliers do not drive our results, for the remainder of the paper we trim the upper and lower 2.5 percentiles of the premium distribution (Panel B). Hypothesis tests of the trimmed average and median premiums being equal to 1.0 are rejected in all eras. (Unless otherwise noted, we determine statistical significance based on a $5 \%$ level throughout the paper.) Our tests of the sample averages assume asymptotic normality of the sample mean normalized by the standard error. To verify the accuracy of the normality assumption, significance levels are verified by nonparametric bootstrap techniques. Statistical tests of the median rely solely on nonparametric bootstrap methods. ${ }^{11}$ For comparisons across eras, we assume independent samples, consistent with the independence assumptions of previous empirical work.

The tax prediction (Hypothesis 1) states that the ex-day premium will fall and abnormal returns increase as the effective capital gains tax rate falls from the $1 / 8$ to the $1 / 16$ and decimal eras. In contrast, Hypothesis 2 implies that price discrete-

\footnotetext{
${ }^{9}$ We use the 5 -second quote adjustment of Lee and Ready (1991) to compute effective spreads.

${ }^{10}$ Consistent with prior literature (e.g., Bessembinder (2001)), we find that quoted depth has fallen in the decimal era. In Section C.1., we investigate the effect of depth on ex-day pricing.

${ }^{11}$ See Efron and Tibshirani (1993) for bootstrapping details.
} 
Table II

Premium Summary Statistics by Era

The sample includes quarterly dividend-paying firms listed on the NYSE. REITs and ADRs are excluded. The $1 / 8$ era is from January 1,1996 to May 6,1997 . The $1 / 16$ era is from June 24,1997 to August 26, 2000. The decimal era is from January 29, 2001 to December 31, 2001. The Premium is defined as $\left(P_{\text {cum }}-P_{\text {ex }}\right) /$ Div. $P$-value $(b)$ is the bootstrap $p$-value for the null hypothesis that the median premium for a given era is equal to one against the alternative that the median premium is less than one. The standard error is for the sample mean. Panel A presents summary statistics for the entire sample. Panel B presents summary statistics after trimming the top and bottom 2.5 percentiles of premium.

\begin{tabular}{lccc}
\hline & \multicolumn{3}{c}{ Era } \\
\cline { 2 - 4 } Statistic & $1 / 8$ & $1 / 16$ & Decimal \\
\hline \multicolumn{2}{c}{ Panel A: Entire Sample } \\
\hline Median & $0.8929^{\mathrm{a}}$ & 0.8333 & $0.7500^{\mathrm{c}}$ \\
$P$-value(b) & $(0.0020)$ & $(0.0000)$ & $(0.0000)$ \\
Mean & 0.8103 & 0.7759 & 1.1538 \\
Standard Error & $(0.1174)$ & $(0.1987)$ & $(0.2816)$ \\
Standard Deviation & 9.2014 & 23.624 & 16.537 \\
Minimum & 260.0 & -1020 & -186.6 \\
Maximum & 125.00 & 1200.0 & 368.50 \\
Skewness & -3.842 & 10.280 & 4.8209 \\
Kurtosis & 150.65 & 1075.0 & 111.93 \\
Observations & 6,145 & 14,142 & 3,448 \\
\hline
\end{tabular}

Panel B: $2.5 \%$ Trimmed Sample

\begin{tabular}{lccc}
\hline Median & $0.8929^{\mathrm{a}}$ & 0.8333 & $0.7500^{\mathrm{c}}$ \\
$P$-value(b) & $(0.0000)$ & $(0.0000)$ & $(0.0000)$ \\
Mean & 0.8269 & 0.7140 & 0.7932 \\
Standard Error & $(0.0485)$ & $(0.0508)$ & $(0.1044)$ \\
Standard Deviation & 3.7037 & 5.8867 & 5.9729 \\
Minimum & -12.50 & -24.31 & -22.00 \\
Maximum & 15.000 & 23.750 & 27.059 \\
Skewness & -0.1805 & -0.1711 & 0.3624 \\
Kurtosis & 2.7861 & 3.4931 & 4.3636 \\
Observations & 5,835 & 13,435 & 3,276 \\
\hline
\end{tabular}

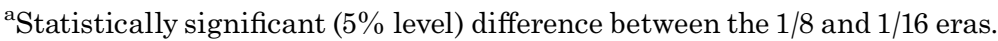

${ }^{\mathrm{c}}$ Statistically significant (5\% level) difference between the $1 / 8$ and decimal eras.

ness (and/or bid-ask bounce) is the driving factor behind the ex-dividend premium puzzle and that the ex-day premium should become closer to 1.0 and abnormal returns closer to 0 as the pricing grid becomes finer. To test these hypotheses, we compare premiums and abnormal returns across eras. Panel B in Table II shows that there is not a statistically significant difference in mean premiums between any of the eras. However, median premiums show a significant reduction from the 1/8 era to the $1 / 16$ and decimal eras. (A superscript "a" ("b") ["c"] in the $1 / 8(1 / 16)$ [decimal] column indicates a significant difference from the 
Table III

\section{Ex-Day Abnormal Return Summary Statistics by Era}

The sample includes quarterly dividend-paying firms listed on the NYSE. REITs and ADRs are excluded. The $1 / 8$ era is from January 1,1996 to May 6, 1997. The 1/16 era is from June 24, 1997 to August 26, 2000. The decimal era is from January 29, 2001 to December 31, 2001. The Ex-Day Abnormal Return is defined as $\left(\left(P_{e x}-P_{\text {cum }}+D i v\right) / P_{\text {cum }}\right)-E R$, where $E R$ is the expected return defined by the market model. Parameter estimation of the expected return model is undertaken with monthly data from the 60 months preceding the month in which the ex-day occurred. $P$-value (b) is the bootstrap $p$-value for the null hypothesis that the median abnormal return for a given era is equal to zero against the alternative that the median abnormal return is greater than zero. The standard error is for the sample mean.

\begin{tabular}{lccr}
\hline & \multicolumn{3}{c}{ Era } \\
\cline { 2 - 4 } Statistic & $1 / 8$ & $1 / 16$ & Decimal \\
\hline Median & 0.0002 & $0.0005^{\mathrm{b}}$ & $0.0027^{\mathrm{c}}$ \\
$P$-value(b) & $(0.0020)$ & $(0.0000)$ & $(0.0000)$ \\
Mean & 0.0004 & $0.0010^{\mathrm{b}}$ & $0.0024^{\mathrm{c}}$ \\
Standard Error & $(0.0002)$ & $(0.0002)$ & $(0.0004)$ \\
Standard Deviation & 0.0171 & 0.0238 & 0.0241 \\
Minimum & 0.1001 & -0.2079 & -0.3515 \\
Maximum & 0.1859 & 0.6970 & 0.2049 \\
Skewness & 0.8977 & 2.2948 & -2.168 \\
Kurtosis & 11.349 & 61.633 & 34.289 \\
Observations & 5,819 & 13,435 & 3,353 \\
\end{tabular}

${ }^{\mathrm{b}}$ Statistically significant (5\% level) difference between the $1 / 16$ and decimal eras.

${ }^{\mathrm{c}}$ Statistically significant (5\% level) difference between the $1 / 8$ and decimal eras.

1/16 (decimal) [1/8] era.) These results are consistent with Hypothesis 1 but are opposite for Hypothesis $2 .^{12}$

Table III presents a similar analysis for the ex-day abnormal return, defined as

$$
\frac{P_{e x, i t}-P_{c u m, i t}+D i v_{i t}}{P_{c u m, i t}}-E\left(R_{i t}\right)
$$

where $E\left(R_{i t}\right)$ is the expected return for firm $i$ on event day $t$, as calculated from the market model:

$$
E\left(R_{i t}\right)=\alpha_{i t}+\beta_{i t}\left(E\left(R_{m t}\right)-R_{f t}\right)
$$

Here, $E\left(R_{m t}\right)$ is the expected return on the market at time $t$ and $R_{f t}$ is the risk-free return at time $t$. Parameter estimation is accomplished using monthly data for

\footnotetext{
${ }^{12}$ The median ex-day premium from the $1 / 8$ era is 0.89 (Table II). If we plug in the capital gains tax rate of $28 \%$, equation (2) implies that the income tax rate for the marginal investor is $36 \%$. Assuming an income tax rate of $36 \%$ in the later eras and plugging in the new capital gains tax rate of $20 \%$ implies that the ex-day premium should equal 0.80 after May 1997, if tax factors drive ex-day pricing. Table II reveals that the median ex-day premiums during the $1 / 16$ and decimal eras are quite close to the 0.80 premium predicted by the tax hypothesis.
} 
the 5 years preceding the event. ${ }^{13}$ The market return is taken as the valueweighted return on all NYSE, AMEX, and Nasdaq stocks and the risk-free rate is the 1-month rate on Treasury bills. We use a monthly data frequency to estimate the market model to be consistent with Bell and Jenkinson (2002). ${ }^{14}$ Mean abnormal returns vary from $0.04 \%$ in the $1 / 8$ era to $0.10 \%$ in the $1 / 16$ era to $0.24 \%$ in the decimal era. Mean (and median) abnormal returns are statistically different from zero under both 1/16 and decimal pricing. During the 1/8 era, the mean abnormal return was not different from zero.

Statistical tests indicate that ex-day abnormal returns increased significantly from the $1 / 8$ and $1 / 16$ eras to the decimal era. The return results in Table III (and the premium results in Table II) are opposite Hypothesis 2 and cast doubt on price discreteness being the primary factor behind ex-day pricing either directly (Bali and Hite (1998)) or indirectly through reduced bid-ask bounce (Frank and Jagannathan (1998)). To the extent that bid-ask spreads measure the relevant costs in ex-day transactions, the results in Tables II and III are also not consistent with the more general transaction cost explanations. However, as we discuss later, because stated depth decreased at the same time as spreads, it is not clear that effective transaction costs, especially for large trades, actually decreased. Finally, the results in Tables II and III are generally consistent with the tax prediction in Hypothesis $1 .^{15,16}$

\section{A.2. Close-to-Open and Midpoint Pricing Using TAQ Data}

Thus far, our analysis has been based on CRSP daily closing prices, which has been the standard methodology in previous research. In this section, we repeat our previous analysis using midquote prices gathered from TAQ for two reasons.

\footnotetext{
${ }^{13}$ Abnormal returns for which there are not at least two years of historical price data are set to missing.

${ }^{14}$ As robustness checks, we calculate abnormal returns using betas estimated from a daily frequency market model (as in Karpoff and Walkling (1990)) and using Fama and French (1992) factors. In both cases, the results are qualitatively similar to those reported.

${ }^{15}$ In untabulated analysis, we compare the premium for the $1 / 8$ era in our main sample (when the capital gains tax rate was $28 \%$ ) to the premium during the last 6 weeks of $1 / 8$ pricing on the NYSE (i.e., from May 7, 1997 to June 23, 1997), when the tax rate fell to $20 \%$. The premium fell statistically significantly further from one in conjunction with the reduction in the capital gains tax rate, which is consistent with the tax hypothesis.

${ }^{16}$ Although the premium was statistically indistinguishable between the 1/16 and decimal eras, abnormal returns increased. This increase in abnormal return cannot be explained by statutory tax rates because they did not change during the 1/16 and decimal eras. However, for 5 months during the 1/16 era, the holding period to qualify for capital gains treatment increased from 12 to 18 months, which could dampen returns in the 1/16 era and explain the difference in mean abnormal returns between the eras. We analyze this possibility by splitting the 1/16 era into three subperiods: June 24, 1997 to July 28, 1997 (20\% tax rate, 12 -month holding period), July 29, 1997 to December 31, 1997 (20\% tax rate, 18-month holding period), and January 1, 1998 through August 26, 2000 (20\% tax rate, 12-month holding period). We find no statistical difference in abnormal returns during these three subperiods and a median premium of exactly 0.833 during all three subperiods. Therefore, we conclude that the differing length of the holding period during the 1/16 era does not significantly affect our results.
} 
First, it allows us to test Hypothesis 2A, which cannot be done using closing prices from CRSP. Closing prices may bias the premium and abnormal return measures due to bid-ask bounce effects. This issue is particularly acute if there is greater buy-side participation by market-makers on the cum day, and on the sell side on the ex-day, as Frank and Jagannathan (1998) argue. Second, if, as some models argue (e.g., Elton and Gruber (1970)), the entire ex-day price movement occurs between the closing price of the cum-day and the opening price of the ex-day, using closing prices on the ex-day adds noise and reduces our ability to make accurate inferences.

To ensure the integrity of the data and our matching procedure, we first use TAQ closing transaction prices and recalculate abnormal returns and premiums. We find almost no difference with the CRSP analysis reported in Tables II and III.

Next, as shown in Panel A of Table IV, we repeat our experiments measuring $P_{\text {cum }}$ and $P_{e x}$ at the close of the trading day but use the midpoint of the bid and ask quotes (rather than transaction prices). Using midpoints should attenuate bidask bounce that might affect traditional ex-day analysis and allow us to directly test the Frank and Jagannathan (1998) bid-ask bounce hypothesis (Hypothesis 2A). Panel A shows that mean and median ex-day premiums are significantly less than 1.0 in all three eras (the decimal era mean is significant at the $10 \%$ level, the $1 / 8$ and $1 / 16$ means are significant at the $5 \%$ level) and that mean and median abnormal returns are greater than zero. The median premium is highest during the $1 / 8$ era with a value of 0.9 and lowest in the decimal era with a value of 0.7353 .

Moreover, within each era, the premiums and returns in Table IV are statistically equal to the premia in Table II and returns in Table III, which are based on closing prices. Therefore, using midpoint prices to eliminate bid-ask bounce makes no statistical difference relative to using transaction prices, indicating that bid-ask bounce in transaction prices is not the primary cause of ex-day pricing in our sample. Clearly, these results are not consistent with Hypothesis 2A, which is based on the premium differing from one because of bid-ask bounce. The results in Table IV are also inconsistent with Hypothesis 2 because the ex-day premium did not become closer to one as the pricing grid became finer. Finally, the statistical equivalence of our results using mid-quote prices from TAQ and closing prices from CRSP suggests that previous research based on CRSP prices is not greatly affected by bid-ask bounce effects.

The second issue we address with TAQ data is the impact of using ex-day closing prices rather than opening prices when calculating the ex-dividend day premium (again, using midquotes). Strictly speaking, in a world of rigid tax clienteles, the price adjustment between the cum- and the ex-day should occur between the cum-day close and the ex-day open. Measuring the premium using the opening ex-day price rather than at the ex-day close can also eliminate noise associated with daily price movements. Panel B of Table IV shows that, close-toopen, the median premium declines from 0.94 in the $1 / 8$ era to 0.83 in the $1 / 16$ era to 0.82 in the decimal era. The $1 / 16$ and decimal premia are significantly less than the $1 / 8$ premium, but not significantly different from each other. To account for a lower expected overnight return (relative to the daily return), overnight abnormal returns are computed by subtracting one half of the expected daily return. 


\section{Table IV}

\section{Premiums and Ex-Day Abnormal Returns by Era Using Quote Midpoints}

The sample includes quarterly dividend-paying firms listed on the NYSE that have information available in both CRSP and TAQ databases. REITs and ADRs are excluded. The 1/8 era is from January 1, 1996 to May 6, 1997. The 1/16 era is from June 24, 1997 to August 26, 2000. The decimal era is from January 29,2001 to December 31,2001 . The Premium is defined as $\left(P_{\text {cum }}-P_{\text {ex }}\right) /$ Div and is trimmed by setting values in the top and bottom 2.5 percentiles to missing. The Ex-Day Abnormal Return is defined as $\left(\left(P_{e x}-P_{\text {cum }}+D i v\right) / P_{\text {cum }}\right)-E R$, where $E R$ is the expected return defined by the market model. Parameter estimation of the expected return model is undertaken with monthly data from the 60 months preceding the month in which the ex-day occurred. P-value(b) is the bootstrap $p$-value for: (1) the null hypothesis that the median Premium for a given era is equal to one against the alternative that the median Premium is less than one and (2) the null hypothesis that the median Ex-Day Abnormal Return for a given era is equal to zero against the alternative that the median Ex-Day Abnormal Return is greater than zero. The $P_{\text {cum }}$ is computed using the midpoint of the closing quote on the cum-day. In Panel A, $P_{e x}$ is computed using the midpoint of the closing quote on the ex-day. In Panel B, $P_{e x}$ is computed using the midpoint of the opening quote (first quote after 9:35 a.m.) on the ex-day. Overnight abnormal returns in Panel $B$ are adjusted by subtracting off one half of the estimated expected return. The standard error of the sample mean is denoted by $S E$.

\begin{tabular}{|c|c|c|c|c|c|c|}
\hline \multirow{3}{*}{ Statistic } & \multicolumn{3}{|c|}{ Premium } & \multicolumn{3}{|c|}{ Ex-Day Abnormal Return } \\
\hline & $\begin{array}{l}1 / 8 \\
\text { Era }\end{array}$ & $\begin{array}{l}1 / 16 \\
\text { Era }\end{array}$ & $\begin{array}{c}\text { Decimal } \\
\text { Era }\end{array}$ & $\begin{array}{l}1 / 8 \\
\text { Era }\end{array}$ & $\begin{array}{l}1 / 16 \\
\text { Era }\end{array}$ & $\begin{array}{c}\text { Decimal } \\
\text { Era }\end{array}$ \\
\hline & \multicolumn{5}{|c|}{ Panel A: Close to Close } & \\
\hline Median & $0.9000^{\mathrm{a}}$ & 0.8152 & $0.7353^{\mathrm{c}}$ & 0.0003 & $0.0004^{\mathrm{b}}$ & $0.0027^{\mathrm{c}}$ \\
\hline$P$-Value(b) & $(0.0010)$ & $(0.0000)$ & $(0.0000)$ & $(0.0180)$ & $(0.0020)$ & $(0.0000)$ \\
\hline Mean & 0.8313 & 0.7520 & 0.8063 & 0.0005 & $0.0009^{b}$ & $0.0024^{\mathrm{c}}$ \\
\hline SE & 0.0494 & 0.0529 & 0.1055 & 0.0002 & 0.0002 & 0.0004 \\
\hline Observations & 5,446 & 11,958 & 3,081 & 5,492 & 12,035 & 3,158 \\
\hline \multicolumn{7}{|c|}{ Panel B: Close to Open } \\
\hline Median & $0.9375^{\mathrm{a}}$ & 0.8333 & $0.8235^{\mathrm{c}}$ & 0.0001 & $0.0005^{\mathrm{b}}$ & $0.0018^{\mathrm{c}}$ \\
\hline$P$-Value(b) & $(0.000)$ & $(0.0000)$ & $(0.0000)$ & $(0,538)$ & $(0.0030)$ & $(0.0000)$ \\
\hline Mean & $1.0096^{\mathrm{a}}$ & 0.8078 & $0.8574^{\mathrm{c}}$ & $0.0000^{\mathrm{a}}$ & 0.0009 & $0.0013^{\mathrm{c}}$ \\
\hline SE & 0.0207 & 0.0200 & 0.0448 & 0.0001 & 0.0002 & 0.0003 \\
\hline Observations & 5,446 & 11,958 & 3,081 & 5,492 & 12,035 & 3,158 \\
\hline
\end{tabular}

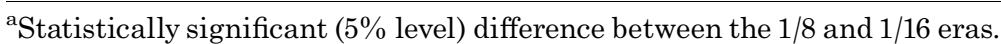

${ }^{\mathrm{b}}$ Statistically significant (5\% level) difference between the $1 / 16$ and decimal eras.

${ }^{\mathrm{c}}$ Statistically significant (5\% level) difference between the $1 / 8$ and decimal eras.

This adjustment is motivated by a comparison of average overnight and average daily returns to the most liquid (i.e., largest trading volume) S\&P 500 futures contract over the period April 21, 1982 to March 30, 2001. ${ }^{17}$ Median abnormal returns increase from $0.01 \%$ to $0.05 \%$ to $0.18 \%$ across eras. This is opposite the pattern that should occur if price discreteness or bid-ask effects are the dominant

${ }^{17}$ We thank Bob Whaley for suggesting this analysis and for providing the data. 
factors causing the ex-day phenomenon. These results confirm what we found in Tables II and III, namely, that price discreteness and bid-ask bounce do not appear to drive ex-day returns. Instead, the premium and abnormal return results are consistent with the ex-day tax effects predicted in Hypothesis 1.

Finally, comparing the close-to-close (Panel A) and close-to-open results (Panel B) shows that for any given era, most, if not all, of the ex-dividend price adjustment occurs from close to open. However, it also indicates that for our sample, there is no substantial drawback to using closing prices for ex-day analysis.

\section{B. Portfolios Based on Dividend Yield (Tests of Hypothesis 3)}

The microstructure theories imply that the positive relation between the premium and dividend yield occurs because the relative importance of microstructure effects relative to dividends declines with the size of the dividend. This implies that the association between dividend yield and ex-day premiums and returns should decline as the pricing grid becomes finer (Hypothesis 3) because of a reduction in price discreteness (Bali and Hite (1998)), bid-ask bounce (Frank and Jagannathan (1998)), or transaction costs (to the extent that bid-ask spread measures the relevant transaction cost). In Table V, we sort sample firms into five groups based on the following quarterly dividend yield categories (right-endpoint inclusive): $0 \%$ to $0.5 \%, 0.5 \%$ to $1 \%, 1 \%$ to $1.5 \%, 1.5 \%$ to $2 \%$, and greater than $2 \%$. The number of observations in each subgroup varies, but in unreported analysis, our results are the same if we instead group the stocks into dividend yield quintiles.

Like previous research, we find that the premium increases as the dividend yield increases. For all three eras, the median premium for events with dividend yields less than $1 \%$ is significantly less than that for events with dividend yields above $1 \%$ (to avoid complicating Table V, these statistical tests are not shown in the table). Similarly, the median premium from the highest dividend yield group is statistically larger than the median premium in the lowest dividend yield group in the $1 / 16$ and decimal eras-but not in the $1 / 8$ era.

To determine if this association has changed across eras, we note that the difference between the median premiums in the highest and lowest dividend yield groups is largest in the decimal era (0.5391 vs. 0.2626 in the $1 / 16$ era and 0.3017 in the $1 / 8$ era), which is inconsistent with Hypothesis 3 . Further, in Table V, abnormal returns show no clear pattern across dividend yield groups within any of the pricing eras. Across eras, abnormal returns are greater in the decimal era than in the other eras, and, if anything, decline more precipitously with dividend yield in the decimal era, opposite Hypothesis 3.

Overall, we find no evidence that the relation between either premiums or returns and dividend yield weakens in the 1/16 or decimal era. If anything, the relation becomes more pronounced. This finding does not support the predictions in Hypothesis 3. It is hard to explain the similarity between the eras if microstructure effects related to bid-ask spreads or price discreteness are the primary factors leading to abnormal ex-day returns, because large changes in spreads and 

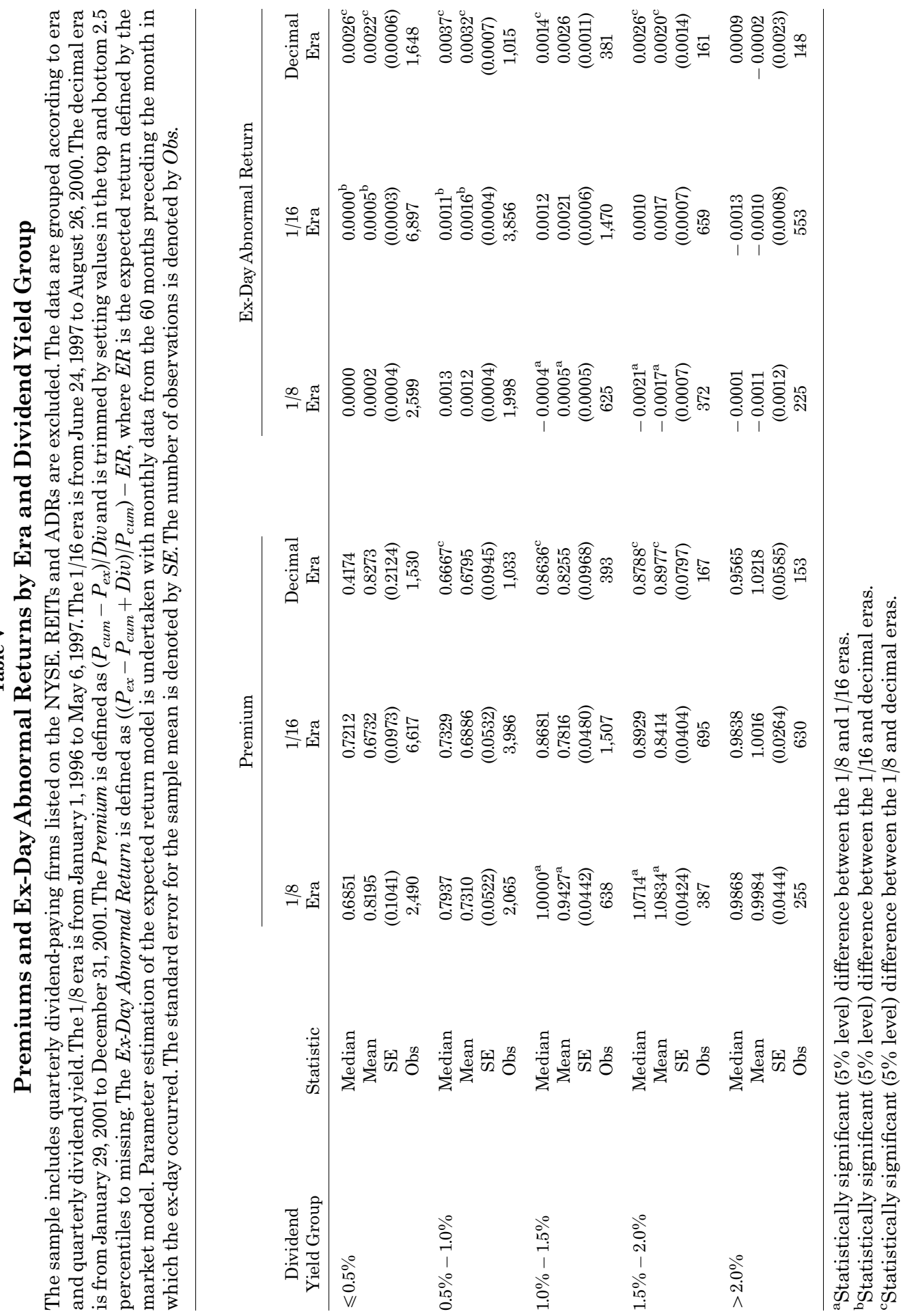
discreteness do not lead to changes in the relation between ex-day pricing and dividend yield. These results are inconsistent with both Bali and Hite (1998) and Frank and Jagannathan (1998).

\section{Transaction Cost Explanations of Ex-day Behavior}

The preceding sections indicate that neither price discreteness nor bid-ask bounce alone is the reason for the observed ex-dividend day price behavior. However, examining bid-ask spreads averaged within eras is not sufficient to test transaction cost models. First, these transaction cost models have implications about changes in ex-day pricing (Hypothesis 4) and volume (Hypothesis 5) that we have not yet tested. So far we examined whether the minimum spread of a given era affects ex-day pricing. In this section, we investigate the relation between the actual reduction in spreads and ex-day pricing and volume behavior. Second, the bid-ask spread is not the only component of transaction costs. For example, depth is also a component of transaction costs, and in the next section, we consider whether the evolution of depth during the sample period affects ex-day pricing.

\section{C.1. Transactions Costs and Ex-dividend Day Pricing (Tests of Hypothesis 4)}

Hypothesis 2 states that a decline in transaction costs should cause the premium to be closer to one, and Hypothesis 4 asserts that this movement should be greatest for stocks with the largest reduction in transaction costs. Equivalently, abnormal returns should be closer to zero. Thus, the expectation is that the change in the ex-day premium for firms experiencing a significant decline in transaction costs should be positive. Stocks that experience a larger reduction in transaction costs should also experience a bigger change in their ex-day return (towards zero).

To test this hypothesis, we perform several cross-sectional regressions of the change in abnormal return on the changes in (i) the average ex-day bid-ask spread, (ii) average depth, and (iii) the average dividend yield. ${ }^{18}$ This enables us to determine whether changes in the bid-ask or depth component of transactions costs affects ex-day returns, holding the impact of dividend yield changes constant. We perform three regressions: change from $1 / 8$ into $1 / 16$, change from $1 / 16$ into decimal, and change from $1 / 8$ into decimal. As shown in Table VI, the explanatory variables generally do not explain the change in abnormal returns in a statistically significant manner. We also perform a similar (unreported) regression using the change in the ex-day premium as the dependent variable; none of the variables are significant. ${ }^{19}$

\footnotetext{
${ }^{18}$ For each event, depth is computed as the average of the bid and offer depth during the day. The level of depth around the ex-day significantly decreases from 1/8 to $1 / 16$ to decimal pricing. For example, median ex-day depth decreases from 5,000 to 2,650 to 850 shares.

${ }^{19}$ We also perform the same regressions on the subsample of firms that have a dividend yield of more than $1 \%$. The estimated coefficients show a slightly stronger, but still insignificant, association.
} 


\section{TableVI}

\section{Explaining the Change in Ex-Day Abnormal Return across Eras}

The sample includes quarterly dividend-paying firms listed on the NYSE that have information available in both CRSP and TAQ databases. REITs and ADRs are excluded. All variables are measured at the firm level, averaged across ex-day observations within an era. The table reports three OLS regressions corresponding to changes between the $1 / 16$ era and the $1 / 8$ era $\left(1 / 16^{\text {th }}-1 / 8^{\text {th }}\right)$, decimal and the $1 / 16$ (Decimal $\left.-1 / 16^{\text {th }}\right)$, and decimal and the $1 / 8\left(\right.$ Decimal $\left.-1 / 8^{\text {th }}\right)$ :

$$
y=\beta_{0}+\beta_{1}(\Delta \mathrm{B} / \mathrm{A} \text { Spread })+\beta_{2}(\Delta \mathrm{Depth})+\beta_{3}(\Delta \mathrm{Div} \text { Yield })+\varepsilon .
$$

The dependent variable $(y)$ is the change in average ex-day abnormal return. The $\Delta B / A$ Spread is the change in average bid-ask spread on the ex-day. The $\Delta$ Depth is the change in average depth (measured in lots of 10,000 shares). The $\Delta$ Div Yield is the change in average dividend yield. Standard errors are in parentheses and are heteroskedastic consistent (White (1980)).

\begin{tabular}{lccc}
\hline & \multicolumn{3}{c}{ Era } \\
\cline { 2 - 4 } Coefficient & $1 / 16-1 / 8$ & Decimal $-1 / 16$ & Decimal $-1 / 8$ \\
\hline Intercept $\left(\beta_{0}\right)$ & 0.0005 & 0.0003 & 0.0021 \\
& $(0.0004)$ & $(0.0008)$ & $(0.0010)$ \\
$\Delta$ B/A Spread $\left(\beta_{1}\right)$ & -0.0000 & -0.0015 & 0.0071 \\
& $(0.0006)$ & $(0.0005)$ & $(0.0068)$ \\
$\Delta$ Depth $\left(\beta_{2}\right)$ & -0.0007 & -0.0012 & -0.0009 \\
& $(0.0007)$ & $(0.0030)$ & $(0.0010)$ \\
$\Delta$ Div Yield $\left(\beta_{3}\right)$ & -0.1350 & -0.2356 & 0.1931 \\
Observations & $(0.2406)$ & $(0.3792)$ & $(0.2153)$ \\
\hline
\end{tabular}

The regression analysis in Table VI assumes linear relations between the variables. To allow for possible nonlinearities, we perform an unreported nonparametric examination of this same issue based on sorting by the change in bid-ask spreads from the $1 / 16$ to the decimal era (and, separately, for the $1 / 8$ to the decimal era). Consistent with the regression analysis, we do not find any clear association between the change in transaction costs (measured by the change in the bid-ask spread) and changes in ex-day abnormal returns. Finally, in both regressions and nonparametric analyses, the change in bid-ask spreads does not have a significant effect on stocks that had the largest abnormal volume during the 1/16 era (or, separately, the 1/8 era) - these are the stocks that are most likely to have been subject to arbitrage activity (which may have been constrained by bid-ask spreads). ${ }^{20}$ Overall, we find no evidence that changes in bid-ask spreads and changes in depth affect ex-day pricing.

\footnotetext{
${ }^{20}$ To highlight any changes among high volume stocks, we repeat the abnormal return regressions using only firms with positive abnormal ex-day trading volume. The results are unchanged except for a significantly negative coefficient on the change in dividend yield in the $1 / 16$ to $1 / 8$ era regression.
} 


\section{C.2. Transactions Costs and Ex-Dividend Day Volume (Tests of Hypothesis 5)}

Research about volume in the United States (Lakonishok and Vermaelen (1986) and Michaely and Vila (1996)), Italy (Michaely and Murgia (1995)), Japan (Kato and Loewenstein (1995)), and Sweden (Green and Rydqvist (1999)) indicates that there is abnormal trading activity around the ex-day. The abnormal trading activity is positively related to the magnitude of the dividend and negatively related to the level of transaction costs and risk. These results are consistent with the possibility that abnormal ex-day trading activity is related to differential taxes and arbitrage or dividend capture.

We examine trading activity during the 11-day event window encompassing the ex-day. Turnover is the aggregate number of shares traded on a given day divided by the number of outstanding shares. Normal volume for an event is computed by finding the average daily turnover for the 80 days from day -45 to +45 (relative to the ex-day), not including days -5 to +5 . Abnormal volume for each day in the event window is computed by taking the ratio of turnover for that day to normal turnover and subtracting one. Cumulative abnormal volume in a given day is the sum of the abnormal volumes from the preceding days in the event window.

Normal trading volume (i.e., not in the event window) increased significantly in recent years. Average daily turnover is $0.29 \%$ in the $1 / 8$ era, $0.36 \%$ in the $1 / 16$ era, and $0.47 \%$ in the decimal era (not tabulated). Thus, average non-ex-day related daily turnover increased by $24 \%$ from the $1 / 8$ to the $1 / 16$ pricing era and by $31 \%$ from the $1 / 16$ to the decimal pricing era.

Table VII indicates that volume is higher during the ex-day (day 0) than it is during nonevent days. On average, turnover is $30 \%$ higher than normal on the ex-day during the $1 / 8$ era, $33 \%$ higher during the $1 / 16$ era, and $34 \%$ higher during the decimal era (Panel A). Lakonishok and Vermaelen (1986), Karpoff and Walkling (1990), and Michaely and Vila (1995) argue that abnormal volume just before and just after a stock goes ex-dividend is consistent with dividend capture, in which low-tax (or tax neutral) traders acquire shares to capture the dividend, then sell the shares shortly after the ex-day. If transaction costs are a deterrent to ex-day trading (and bid-ask spreads are the dominant measure of transaction costs), the reduction in bid-ask spread that occurs as the market moves to decimals should lead to an increase in abnormal volume (Hypothesis 5). We do not find that this is the case: Decimal era cumulative abnormal volume is not statistically different than in the $1 / 16$ era and is less than in the $1 / 8$ era. If anything, cumulative abnormal volume decreased as the market moved to narrower minimum spreads and lower transaction costs. This decline is due to the increase in normal volume (relative to volume in the ex-day window) across eras.

Panel B of Table VII shows that most of the abnormal volume activity occurs in stocks with dividend yields above $1 \%$. This is consistent with greater dividend capture activity where the payoff to such activity is highest (Koski and Michaely (2000)). The volume numbers also imply that, within any era, it is much less likely that dividend capture or arbitrage activity is important in the smallest two dividend yield groups. More importantly for our paper, note that abnormal volume increased from the $1 / 8$ to the $1 / 16$ era for stocks with quarterly dividend yields 
between $1 \%$ and $1.5 \%$, but not for stocks with yield greater than $1.5 \%$. Moreover, abnormal volume did not significantly increase in the decimal era relative to either of the other two eras (for stocks with yield greater than $0.5 \%$ ). Overall, there is very little evidence that shrinking bid-ask spreads led to increased exdividend related trading, even among high dividend yield stocks.

\section{Table VII}

\section{Abnormal Volume by Era}

The sample includes quarterly dividend-paying firms listed on the NYSE. REITs and ADRs are excluded. The $1 / 8$ era is from January 1,1996 to May 6,1997. The 1/16 era is from June 24, 1997 to August 26, 2000. The decimal era is from January 29, 2001 to December 31, 2001. Abnormal volume (AV) on event day $i$ is defined as the ratio of turnover (volume/shares outstanding) on day $i$ to normal turnover, where normal turnover is computed as the average turnover during the 80 days surrounding each 11-day ex-dividend day window. Cumulative abnormal volume (CAV) is the sum of the abnormal volumes up to and including that day. Panel A presents abnormal volume and cumulative abnormal volume for each day in the 11-day event window (ex-day $=0$ ). Panel B presents abnormal volume on the ex-day by dividend yield group. Standard errors for the sample mean are in parentheses.

\begin{tabular}{|c|c|c|c|c|c|c|}
\hline \multirow[b]{2}{*}{ Event Day } & \multicolumn{3}{|c|}{ Mean AV } & \multicolumn{3}{|c|}{ Mean CAV } \\
\hline & 1/8 Era & 1/16 Era & Decimal Era & 1/8 Era & 1/16 Era & Decimal Era \\
\hline \multicolumn{7}{|c|}{ Panel A: Abnormal and Cumulative Abnormal Volume by Event Day } \\
\hline-5 & $\begin{array}{c}0.0697^{\mathrm{a}} \\
(0.0170)\end{array}$ & $\begin{array}{c}0.0149^{b} \\
(0.0092)\end{array}$ & $\begin{array}{r}0.0592 \\
(0.0176)\end{array}$ & $\begin{array}{c}0.0697^{\mathrm{a}} \\
(0.0170)\end{array}$ & $\begin{array}{c}0.0149^{b} \\
(0.0092)\end{array}$ & $\begin{array}{r}0.0592 \\
(0.0176)\end{array}$ \\
\hline-4 & $\begin{array}{c}0.0644^{\mathrm{a}} \\
(0.0170)\end{array}$ & $\begin{array}{c}0.0243 \\
(0.0105)\end{array}$ & $\begin{array}{c}0.0539 \\
(0.0232)\end{array}$ & $\begin{array}{c}0.1342^{\mathrm{a}} \\
(0.0240)\end{array}$ & $\begin{array}{c}0.0392^{\mathrm{b}} \\
(0.0140)\end{array}$ & $\begin{array}{c}0.1131 \\
(0.0291)\end{array}$ \\
\hline-3 & $\begin{array}{c}0.0276 \\
(0.0157)\end{array}$ & $\begin{array}{c}0.0086 \\
(0.0106)\end{array}$ & $\begin{array}{c}0.0241 \\
(0.0192)\end{array}$ & $\begin{array}{c}0.1618^{\mathrm{a}} \\
(0.0287)\end{array}$ & $\begin{array}{c}0.0478^{\mathrm{b}} \\
(0.0175)\end{array}$ & $\begin{array}{c}0.1372 \\
(0.0349)\end{array}$ \\
\hline-2 & $\begin{array}{r}0.0200 \\
(0.0149)\end{array}$ & $\begin{array}{c}0.0194 \\
(0.0099)\end{array}$ & $\begin{array}{r}-0.0042 \\
(0.0196)\end{array}$ & $\begin{array}{r}0.1818^{\mathrm{a}} \\
(0.0323)\end{array}$ & $\begin{array}{c}0.0672 \\
(0.0201)\end{array}$ & $\begin{array}{c}0.1330 \\
(0.0400)\end{array}$ \\
\hline-1 & $\begin{array}{c}0.4915^{\mathrm{a}} \\
(0.0375)\end{array}$ & $\begin{array}{c}0.2784^{\mathrm{b}} \\
(0.0178)\end{array}$ & $\begin{array}{c}0.1800^{c} \\
(0.0269)\end{array}$ & $\begin{array}{c}0.6734^{\mathrm{a}} \\
(0.0495)\end{array}$ & $\begin{array}{c}0.3456 \\
(0.0268)\end{array}$ & $\begin{array}{c}0.3131^{\mathrm{c}} \\
(0.0482)\end{array}$ \\
\hline 0 & $\begin{array}{c}0.2996 \\
(0.0240)\end{array}$ & $\begin{array}{c}0.3335 \\
(0.0210)\end{array}$ & $\begin{array}{r}0.3400 \\
(0.0519)\end{array}$ & $\begin{array}{c}0.9730^{\mathrm{a}} \\
(0.0550)\end{array}$ & $\begin{array}{c}0.6791 \\
(0.0341)\end{array}$ & $\begin{array}{c}0.6531^{\mathrm{c}} \\
(0.0708)\end{array}$ \\
\hline 1 & $\begin{array}{c}0.2752^{\mathrm{a}} \\
(0.0340)\end{array}$ & $\begin{array}{c}0.0556 \\
(0.0128)\end{array}$ & $\begin{array}{c}0.0814^{\mathrm{c}} \\
(0.0662)\end{array}$ & $\begin{array}{c}1.2482^{\mathrm{a}} \\
(0.0647)\end{array}$ & $\begin{array}{c}0.7347 \\
(0.0364)\end{array}$ & $\begin{array}{r}0.7345^{\mathrm{c}} \\
(0.0970)\end{array}$ \\
\hline 2 & $\begin{array}{c}0.5592^{\mathrm{a}} \\
(0.0730)\end{array}$ & $\begin{array}{r}0.0838 \\
(0.0178)\end{array}$ & $\begin{array}{r}0.1399^{c} \\
(0.0592)\end{array}$ & $\begin{array}{c}1.8073^{\mathrm{a}} \\
(0.0975)\end{array}$ & $\begin{array}{c}0.8185 \\
(0.0405)\end{array}$ & $\begin{array}{c}0.8744^{\mathrm{c}} \\
(0.1136)\end{array}$ \\
\hline 3 & $\begin{array}{c}0.0221 \\
(0.0170)\end{array}$ & $\begin{array}{c}0.1125 \\
(0.0896)\end{array}$ & $\begin{array}{c}0.0693 \\
(0.1052)\end{array}$ & $\begin{array}{c}1.8294^{\mathrm{a}} \\
(0.0990)\end{array}$ & $\begin{array}{c}0.9310 \\
(0.0984)\end{array}$ & $\begin{array}{c}0.9436^{\mathrm{c}} \\
(0.1549)\end{array}$ \\
\hline 4 & $\begin{array}{c}0.0205 \\
(0.0152)\end{array}$ & $\begin{array}{c}0.1781 \\
(0.1542)\end{array}$ & $\begin{array}{c}0.1122 \\
(0.1068)\end{array}$ & $\begin{array}{c}1.8499^{\mathrm{a}} \\
(0.1001)\end{array}$ & $\begin{array}{c}1.1091 \\
(0.1829)\end{array}$ & $\begin{array}{c}1.0559^{c} \\
(0.1881)\end{array}$ \\
\hline 5 & $\begin{array}{c}0.0198 \\
(0.0139)\end{array}$ & $\begin{array}{c}0.1172 \\
(0.1014)\end{array}$ & $\begin{array}{c}0.0747 \\
(0.0514)\end{array}$ & $\begin{array}{c}1.8698^{\mathrm{a}} \\
(0.1011)\end{array}$ & $\begin{array}{c}1.2262 \\
(0.2092)\end{array}$ & $\begin{array}{c}1.1306^{\mathrm{c}} \\
(0.1950)\end{array}$ \\
\hline
\end{tabular}


Table VII

(continued)

Panel B: Ex-Day Abnormal Volume by Dividend Yield Group

\begin{tabular}{lccc}
\hline Dividend Yield & $1 / 8$ Era & $1 / 16$ Era & Decimal Era \\
\hline$<0.5 \%$ & 0.0202 & 0.0350 & $0.1408^{\mathrm{c}}$ \\
& $(0.0219)$ & $(0.0215)$ & $(0.0576)$ \\
$0.5 \%-1.0 \%$ & $0.1344^{\mathrm{a}}$ & $0.3044^{\mathrm{b}}$ & 0.1076 \\
& $(0.0366)$ & $(0.0386)$ & $(0.0480)$ \\
$1.0 \%-1.5 \%$ & $1.0206^{\mathrm{a}}$ & 1.4652 & 1.3314 \\
& $(0.1152)$ & $(0.1087)$ & $(0.2901)$ \\
$1.5 \%-2.0 \%$ & $1.7409^{\mathrm{a}}$ & 1.0574 & 1.2561 \\
& $(0.1718)$ & $(0.1124)$ & $(0.4539)$ \\
$>2.0 \%$ & 0.6364 & 0.4683 & 0.5845 \\
& $(0.1006)$ & $(0.0974)$ & $(0.1431)$ \\
\hline
\end{tabular}

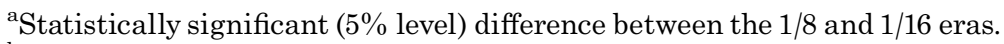

${ }^{\mathrm{b}}$ Statistically significant (5\% level) difference between the $1 / 16$ and decimal eras.

${ }^{\mathrm{c}}$ Statistically significant (5\% level) difference between the $1 / 8$ and decimal eras.

The volume results could imply that the bid-ask component of transactions costs did not constrain ex-dividend trade during earlier pricing eras, because when spreads fell, abnormal volume did not increase. ${ }^{21}$ Alternatively, perhaps bid-ask spreads did constrain trading in the earlier eras; however, risk or other trading costs might have increased in the decimal era (e.g., decreased depth), dampening the increase in volume that might have otherwise occurred following the reduction in bid-ask spreads.

Jones and Lipson (2001) suggest that a consequence of the decrease in minimum spreads is that liquidity has fallen for large trades, consistent with the reduction in ex-day depth we documented earlier. This may inhibit dividend capture and arbitrage trades if reduced liquidity offsets the narrowing of spreads. Under this scenario, the relative importance of large trades could decline as spreads narrow. To examine whether this is true for ex-day trading, we examine volume and the number of trades for large trades (greater than 1,000 shares) and trades with high dividend yield for each era - these are the very trades for which one would expect to find dividend capture and arbitrage.

In unreported analysis, we find that on both ex-days and normal trading days, the number of large trades increased from the $1 / 8$ th to the $1 / 16$ th era and again into the decimal era - but they have not increased as much as have the number of small trades. More importantly for our investigation, as the pricing grid has

\footnotetext{
${ }^{21} \mathrm{We}$ also examine directly whether changes in abnormal volume are associated with changes in bid-ask spreads. The results indicate that ex-day volume changes are not largest for stocks that saw the largest reduction in bid-ask spreads. Nor did ex-day volume change the most among the highest volume stocks.
} 
become finer, large trades have not increased on the ex-day relative to normal trading days in a statistically significant manner. Similarly, trading volume and number of trades in high dividend stocks has increased through time-but it has not significantly increased on ex-days relative to normal trading days, nor for high dividend yield stocks relative to low-yield stocks.

Overall, we find no evidence that reduced bid-ask spreads led to abnormal exday trading for large trades or high-yield stocks. This result is consistent with our earlier statement (based on Table VII) that either bid-ask spreads did not constrain dividend capture and arbitrage trading in the $1 / 8$ era, or else some other cost has increased to offset the reduction in spreads, with the end result being no noticeable increase in dividend capture trading. In contrast, small trades have flourished, particularly among low dividend yield stocks in the decimal era. If small trades are primarily conducted by taxable investors, this may suggest that their tax rates are now more likely to be impounded into ex-day pricing.

In sum, the volume analysis is consistent with abnormal trading occurring before and after a stock goes ex-dividend. However, cumulative abnormal volume does not increase across eras following the reduction in bid-ask spreads, inconsistent with the notion that this component of transaction costs constrained ex-dividend related trading in the $1 / 8$ era. Alternatively, bid-ask spreads might have constrained ex-day trading in earlier eras but, as bid-ask spreads have fallen, liquidity has fallen as well (at least for large trades). This drop in liquidity might now constrain ex-day trading, especially large trades.

\section{Conclusion}

We analyze ex-day price and volume reactions to the dramatic reduction in price discreteness and bid-ask spreads that occurred as the pricing grid changed from $1 / 8$ s to $1 / 16 \mathrm{~s}$ to decimals. If the price discreteness of Bali and Hite (1998) or the bid-ask bounce of Frank and Jagannathan (1998) are the dominant factors driving ex-day activity, then we should observe ex-day premia getting closer to one and abnormal returns approaching zero as the pricing grid becomes finer. In fact, we find the opposite. We also find the same patterns when we base our analysis on midquotes. Taken together, it seems unlikely that either price discreteness or bid-ask bounce explains the patterns in ex-day premiums and abnormal returns on the NYSE.

If the bid-ask spread is the relevant cost restricting arbitrage and dividend capture trading to only the highest dividend stocks in the $1 / 8$ era, one would expect that a reduction in the bid-ask spread would lead to more arbitrage and dividend capture trading, which in turn implies premiums closer to one and increased abnormal volume. However, our analysis of changes in bid-ask spreads does not support this transactions cost prediction. As bid-ask spreads drop precipitously, premiums are not closer to one, abnormal returns are not closer to zero, and abnormal volume generally does not increase for stocks with medium or high divi-dend yields. Our results are consistent with the notion that the decrease in spreads reduced the cost of transaction for small trades, but because liquidity fell at the same time as bid-ask spreads, transaction costs for large trades did not fall. 
Consistent with previous studies, within each era, we find that the premium is closest to one among stocks with the highest dividend yield and abnormal volume is also highest for these stocks. This is consistent with dividend capture or arbitrage activity forcing the premium to approach one for high-dividend yield stocks (because the reward for such activity outweighs the costs). It is also consistent with price discreteness and bid-ask bounce explanations put forth by Bali and Hite (1998) and Frank and Jagannathan (1998), respectively. However, we do not find a change in the association between dividend yield and premiums as price discreteness and bid-ask spreads falls across pricing eras, casting doubt on either of these microstructure explanations being the dominant cause of the positive association between yields and premiums.

Our results are generally consistent with the tax hypothesis that the ex-day premium is caused by preferential taxation of capital gains relative to dividend income. We find that the premium fell when the capital gains tax rate was reduced in May, 1997. That is, as dividends became more disadvantaged relative to capital gains, the premium moved further from one.

In summary, our results are not consistent with the microstructure explanations of the price movement between the cum-day and the ex-dividend day; however, they are consistent with the tax explanation. It is also possible that ex-day pricing patterns are caused by a phenomenon that has not yet been identified in the financial economics literature.

\section{REFERENCES}

Bali, R., and G. L. Hite, 1998, Ex-dividend day stock price behavior: Discreteness or tax-induced clienteles? Journal of Financial Economics 47, 127-159.

Barclay, M., 1987, Dividends, taxes, and common stock prices: The ex-dividend day behavior of common stock prices before the income tax, Journal of Financial Economics 14, 31-44.

Bell, L., and T. Jenkinson, 2002, New evidence on the impact of dividend taxation and on the identity of the marginal investor, Journal of Finance 57, 1321-1346.

Bessembinder, Hendrik, 2001, Trade execution costs and market quality after decimalization, Working paper, University of Utah.

Bollen, Nicolas P. B., and Robert E. Whaley, 1998, Are “teenies" better? The Journal of Portfolio Management Fall, 10-24.

Boyd, J., and R. Jagannathan, 1994, Ex-dividend price behavior of common stocks, Review of Financial Studies 7, 711-741.

Brav, Alon, John R. Graham, Campbell R. Harvey, and Roni Michaely, 2003, Payout policy in the 21st century, Working paper, Duke University.

Dubofsky, David A., 1992, A market microstructure explanation of ex-day abnormal returns, Financial Management, Winter, 32-43.

Eades, Ken, Pat Hess, and E. Han Kim, 1994, Time series variation in dividend pricing, Journal of Finance 49, 1617-1638.

Edwards, Amy, 2001, Are the best quotes good indications of the supply of liquidity? Evidence from decimalization, Working paper, U.S. Securities and Exchange Commission.

Efron, Bradley, and Robert J. Tibshirani, 1993, An Introduction to the Bootstrap (Chapman \& Hall, New York, NY).

Elton, E. J., and M. J. Gruber, 1970, Marginal stockholder tax rates and the clientele effect, Review of Economics and Statistics 52, 68-74.

Fama, Eugene, and Kenneth French, 1992, The cross section of expected stock returns, Journal of Finance 47, 427-465. 
Frank, M., and R. Jagannathan, 1998, Why do stock prices drop by less than the value of the dividend? Evidence from a country without taxes, Journal of Financial Economics 47, 161-188.

Graham, John R., 2003, Taxes and corporate finance: A review, Review of Financial Studies, forthcoming.

Green, R. C., and K. Rydqvist, 1999, Ex-day behavior with dividend preference and limitations to shortterm arbitrage: The case of Swedish lottery bonds, Journal of Financial Economics 53, 145-187.

Jakob, Keith, and Tongshu Ma, 2004, Tick size NYSE rule and ex-dividend 118, day stock price behavior, Journal of Financial Economics, forthcoming.

Jones, Charles M., and Marc Lipson, 2001, Sixteenths: Direct evidence on institutional trading costs, Journal of Financial Economics, forthcoming.

Kadapakkam, P., 2000, Reduction of constraints on arbitrage trading and market efficiency: An examination of ex-day returns in Hong Kong after introduction of electronic settlement, The Journal of Finance 55, 2841-2861.

Kalay, Avner, 1982, The ex-dividend day behavior of stock prices: A re-examination of the clientele effect, Journal of Finance 37, 1059-1070.

Karpoff, Jonathan M., and Ralph A. Walkling, 1988, Short-term trading around ex-dividend days: Additional evidence, Journal of Financial Economics 21, 291-298.

Karpoff, Jonathan M., and Ralph A. Walkling, 1990, Dividend capture in Nasdaq stocks, Journal of Financial Economics 28, 39-66.

Kato, Kiyoshi, and Uri Loewenstein, 1995, The ex-dividend-day behavior of stock prices: The case of Japan, Review of Financial Studies 8, 817-847.

Koski, Jennifer, and Roni Michaely, 2000, Prices, liquidity and the information content of trades, Review of Financial Studies 13, 659-696.

Lakonishok, Joseph, and Theo Vermaelen, 1986, Tax induced trading around ex-dividend dates, Journal of Financial Economics 16, 287-319.

Lee, Charles M., and Mark J. Ready, 1991, Inferring trade direction from intraday data, Journal of Finance 46, 733-746.

Litzenberger, Robert, and Krishna Ramaswamy, 1979, The effect of taxes and dividends on capital asset prices: Theory and empirical evidence, Journal of Financial Economics 7, 163-195.

McDonald, R., 2001, Cross-border investing with tax arbitrage: The case of German dividend tax credits, Review of Financial Studies 14, 617-657.

Michaely, Roni, 1991, Ex-dividend day stock price behavior: The case of the 1986 Tax Reform Act, Journal of Finance 46, 845-860.

Michaely, Roni, and Maurizio Murgia, 1995, The effect of tax heterogeneity on prices and volume around the ex-dividend day: Evidence from the Milan Stock Exchange, Review of Financial Studies 8, 369-399.

Michaely, Roni, and Jean-Luc Vila, 1995, Investors' heterogeneity, prices and volume around the ex-dividend day, Journal of Financial and Quantitative Analysis 30, 171-198.

Michaely, Roni, and Jean-Luc Vila, 1996, Trading volume with private valuations: Evidence from the ex-dividend day, Review of Financial Studies 9, 471-510.

Michaely, Roni, Jean-Luc Vila, and Jiang Wang, 1997, A model of trading volume with tax-induced heterogeneous valuation and transaction costs, Journal of Financial Intermediation 5, 340-371.

New York Stock Exchange, 2001, NYSE Report: Decimalization of trading on the New York Stock Exchange: A report to the Securities and Exchange Commission.

Stoll, Hans, and Robert Whaley, 1983, Transactions costs and the small firm effect, Journal of Financial Economics 12, 57-79.

Stoll, Hans, and Robert Whaley, 1990, Stock market structure and volatility, Review of Financial Studies 3, 37-71.

White, Halbert, 1980, A heteroskedasticity-consistent covariance matrix estimator and a direct test for heteroskedasticity, Econometrica 48, 817-838. 
